\title{
Effect of resource availability on bacterial community responses to increased temperature
}

\author{
Rickard Degerman ${ }^{1}$, Julie Dinasquet ${ }^{2}$, Lasse Riemann ${ }^{2,3}$, Sara Sjöstedt de Luna ${ }^{4}$, \\ Agneta Andersson ${ }^{1, *}$ \\ ${ }^{1}$ Department of Ecology and Environmental Sciences and ${ }^{4}$ Department of Mathematics and Mathematical Statistics, \\ Umeå University, Umeå 901 87, Sweden \\ ${ }^{2}$ Department of Natural Sciences, Linnaeus University, Kalmar 39182, Sweden \\ ${ }^{3}$ Marine Biological Section, Department of Biology, University of Copenhagen, Helsingør 3000, Denmark
}

\begin{abstract}
Climate change is predicted to cause higher temperatures and increased precipitation, resulting in increased inflow of nutrients to coastal waters in northern Europe. This has been assumed to increase the overall heterotrophy, including enhanced bacterial growth. However, the relative importance of temperature, resource availability and bacterial community composition for the bacterial growth response is poorly understood. In the present study, we investigated effects of increased temperature on bacterial growth in waters supplemented with different nutrient concentrations and inoculated with microbial communities from distinct seasonal periods. Seven experiments were performed in the northern Baltic Sea spanning an entire annual cycle. In each experiment, bacterioplankton were exposed to 2 temperature regimes (in situ and in situ $+4^{\circ} \mathrm{C}$ ) and 5 nutrient concentrations. Generally, elevated temperature and higher nutrient levels caused an increase in the bacterial growth rate and a shortening of the response time (lag phase). However, at the lowest nutrient concentration, bacterial growth was low at all tested temperatures, implying a stronger dependence on resource availability than on temperature for bacterial growth. Furthermore, data indicated that different bacterial assemblages had varying temperature responses and that community composition was strongly affected by the combination of high nutrient addition and high temperature. These results support the concern that climate change will promote heterotrophy in aquatic systems, where nutrient levels will increase considerably. In such environments, the bacterial community composition will change, their growth rates will increase, and their response time will be shortened compared to the present situation.
\end{abstract}

KEY WORDS: Temperature increase $\cdot$ Resource availability $\cdot$ Bacterial growth response $\cdot$ Climate change $\cdot$ Community dynamics

\section{INTRODUCTION}

Projections of future climate change indicate increased temperature and precipitation in northern Europe (Cubasch et al. 2001, HELCOM 2007). In aquatic systems, one possible outcome of increased temperature is an altered ratio of heterotrophic to autotrophic production, given that increased temperature in general is more beneficial for heterotrophic organisms than for autotrophic ones (e.g. Hoppe et al. 2002, Müren et al. 2005, Sommer \& Lengfellner 2008). Consequently, heterotrophic bacterioplankton may be favored by increasing temperature, while phytoplankton growth may even be negatively affected (Sommer et al. 2007), leading to a higher proportion of the overall production originating from heterotrophs (Hoppe et al. 2008).

However, for poikilothermic organisms, like bacteria, the basal metabolic rate and consequently the energy demand grows with increasing temperature 
(e.g. Clarke \& Fraser 2004). Hence, at low food resource availability, increased temperature may have a negative effect on growth because basal metabolism increases while the energy needed is not available. If instead food resources are replete, the organisms have a surplus of energy, which can be invested in biomass growth. Under such conditions, the 'biomass growth window' would increase with temperature up to a certain point where enzymes and other cellular processes cease to function. Hence, the bacterial growth response becomes more complex if resource availability varies in concert with temperature (Reay et al. 1999, Pomeroy \& Wiebe 2001). For aquatic ecosystems, which will experience increased run-off from land, e.g. lakes and coastal areas in northern Europe (Andréasson et al. 2004), climate change will cause an elevated inflow of nutrients and dissolved organic matter (DOM) (Eriksson Hägg et al. 2010). Depending on the bioavailability, this will supposedly favor heterotrophy relative to autotrophy since phytoplankton growth will be hampered by the poor light climate imposed by increased concentrations of brown humic-rich DOM (Jones 1992, Klug 2002). Bacteria may in such environments not be as dependent on phytoplankton produced carbon since allochthonous carbon may be available for growth (Bergström et al. 2003, Sandberg et al. 2004, Berglund et al. 2007). The bacterial growth response to increased temperature may thus be larger in nutrient-rich rather than in nutrient-poor environments.

Even though there is a low energy cost at low temperatures, the bacterioplankton have higher requirements for substrates at the lowest temperatures. This is probably due to a lowered substrate affinity (Nedwell 1999), possibly linked to a decreased fluidity of the cell membrane caused by a stiffening of the membrane lipids (Gounot 1991, Jumars et al. 1993). Hence, at low temperatures, even a slight warming would result in an increased substrate affinity (Nedwell 1999). Such a non-linear substrate-temperature relationship has been observed when temperatures approach the lower limit for growth (Reay et al. 1999, Pomeroy \& Wiebe 2001). Decreased temperature has also been found to cause a longer lag-phase (response time) of bacterioplankton growth (Kirchman \& Rich 1997). These mechanisms seem to be general at the community level; however, due to species-specific responses to temperature (e.g. Bidle et al. 2002, Fuhrman et al. 2006) and substrate degradation (Martinez et al. 1996) and uptake (Riemann \& Azam 2002), it is likely that the influence of temperature and substrate availability on community growth is linked to bacterial community composition. Indeed, field data indicate dominance of high-nutrient demanding bacteria during the cold nutrient-rich spring bloom and occurrence of 'oligotrophic' species during the nutrient-poor warm summer (Pinhassi \& Hagström 2000). Hence, throughout a yearly cycle, bacterial assemblages have different adaptations and specializations whereby they respond to variations in temperature and nutrient levels.

The aim of the present study was to evaluate the potential effects of a small increase in temperature in waters with different nutrient status. We hypothesized that nutrient availability in general would have a larger effect on bacterial growth than temperature variations. Accordingly, in oligotrophic systems, bacterioplankton growth would not be affected by elevated seawater temperatures due to nutrient depletion, whereas in nutrient-rich waters, a temperature increase would stimulate bacterial growth. Furthermore, we hypothesized that different bacterial assemblages would respond differently to changes in temperature and resource availability. If so, changes in temperature and nutrients may alter community composition, which in turn might affect ecosystem function. To test these hypotheses, we conducted experiments during different periods of an annual cycle in a temperate sea area, the northern Baltic Sea, where nutrient availability and temperature were varied.

\section{MATERIALS AND METHODS}

\section{Sample collection}

Water was collected at an off-shore station (C14) in the northern Baltic Sea (Bothnian Sea, 62 05' 99" N, $18^{\circ} 32^{\prime} 91^{\prime \prime} \mathrm{E}$ ), using a Rosette water sampler (SBE 32) at $2 \mathrm{~m}$ depth on 7 separate occasions during a complete annual cycle. Sample collection dates were as follows (in situ temperatures given in parentheses): 3 December $2007\left(4^{\circ} \mathrm{C}\right), 25$ March $2008\left(1^{\circ} \mathrm{C}\right), 19$ May $2008\left(4^{\circ} \mathrm{C}\right), 11 \mathrm{June} 2008\left(11^{\circ} \mathrm{C}\right), 23$ June $2008\left(14^{\circ} \mathrm{C}\right)$, 28 July $2008\left(16^{\circ} \mathrm{C}\right)$ and 1 December $2008\left(4^{\circ} \mathrm{C}\right)$. During transport to the laboratory $(\sim 24 \mathrm{~h})$, the water was maintained at in situ temperature $\pm 0.5^{\circ} \mathrm{C}$.

\section{Seawater growth matrix}

Bacterial growth experiments were carried out in low-nutrient seawater (LNS) produced as follows: in September 2007, 150 l of water was collected from 
$5 \mathrm{~m}$ depth at Stn C14, using a peristaltic pump. The water was incubated in a $500 \mathrm{l}$ barrel at 10 to $15^{\circ} \mathrm{C}$ with a diurnal cycle of $12 \mathrm{~h}$ light (Xenon lamp, average light $\sim 100 \mu \mathrm{mol}$ quanta $\mathrm{m}^{-2} \mathrm{~s}^{-1}$ ) and $12 \mathrm{~h}$ darkness. The barrel was covered with a plastic film to avoid contamination. After $\sim 2$ mo of incubation, particles and organisms were excluded by gentle filtration $(<100 \mathrm{~mm} \mathrm{Hg})$ through $0.22 \mu \mathrm{m}, 142 \mathrm{~mm}$ polycarbonate filters (GE healthcare). This procedure reduced the plankton organisms to $\sim 0.1 \%$ of that in the unfiltered water. The total $\mathrm{C}, \mathrm{N}$ and $\mathrm{P}$ concentrations in the LNS were 583, 18.3 and $0.17 \mu \mathrm{mol} \mathrm{l} \mathrm{l}^{-1}$, respectively (Table 1 ). The filtered water was stored frozen until use. Freezing may have precipitated part of the DOC (Fellman et al. 2008), which was consistent with the purpose to obtain a low-nutrition base-medium.

\section{Growth experiments}

The effects of temperature and nutrient availability on bacterial growth were studied on 7 separate occasions following each sample collection event. Polystyrene cell culture flasks $(750 \mathrm{ml})$ with filter-vented caps were filled with $450 \mathrm{ml}$ of LNS and amended with 3 different concentrations of yeast extract (YE; Bacto yeast extract, DIFCO laboratories) (Table 1). One further series without any YE addition acted as control. All treatments were carried out in triplicate. The YE had a near Redfield molecular ratio of 95:17:1 (C:N:P). Levels of total phosphorus in the different treatments simulated ultra-oligotrophic $(0.17$, 0.19 and $0.22 \mu_{m o l ~ ~^{-1}}$; Table 1) and mesotrophic $\left(0.68 \mu \mathrm{mol} \mathrm{l}^{-1}\right)$ conditions (Swedish Environmental Protection Agency 1999), which correspond to the lowest and middle trophic state index (Carlson 1977). The YE was used to establish different trophic states of the water, i.e. the YE simulated varying amounts of produced organic $\mathrm{C}, \mathrm{N}$ and $\mathrm{P}$, which potentially would be available as food source for heterotrophic bacteria.

The flasks were inoculated with $50 \mathrm{ml}$ of $0.65 \mu \mathrm{m}$ filtered (polycarbonate filters; GE Healthcare) water, obtaining an initial concentration of $\sim 10^{5}$ bacteria $\mathrm{ml}^{-1}$. This filtration altered the bacterial communities in some cases but was necessary to remove predators (protozoa). No protozoa could be detected during the experiment by microscopic analysis. Flasks were incubated in the dark at in situ temperature or at in situ $+4^{\circ} \mathrm{C}$ for 60 to $216 \mathrm{~h}$ to ensure inclusion of the entire exponential growth phase. In situ $+4^{\circ} \mathrm{C}$ was chosen to mimic the expected climate-induced temperature increase in northern Europe of 2.5 to $4.6^{\circ} \mathrm{C}$ (Andréasson et al. 2004) or 1.9 to $3.3^{\circ} \mathrm{C}$ in the Baltic proper (Meier 2006). In one of the experiments (December 2008), the temperature was increased $10^{\circ} \mathrm{C}$ to study effects of larger changes in temperature. During the winter and spring experiments, sampling for bacterial abundance and biomass was done once a day, while in summer, sampling was conducted twice a day. Samples for bacterial community composition analysis were obtained at the beginning and end of each experiment.

Bacterial abundance, biomass and growth rate were determined from formaldehyde-fixed samples ( $4 \%$ final concentration). Cells were stained with acridine orange and filtered onto black $0.2 \mu \mathrm{m}$ polycarbonate filters (GE Healthcare). Cell counts were determined using an epifluorescence microscope (Zeiss Axiovert 100) with a camera (Hamamatsu ORCA-ER) and the image analysis programs LabMicrobe (Blackburn et al. 1998) and LabDatabase (www.bioras.com). The filtered volume was adjusted ( 0.1 to $10 \mathrm{ml}$ ) to get an appropriate number of bacteria per image. Seven images were taken for each slide, yielding $\sim 300$ to 1000 counted cells per slide. Carbon biomass was estimated from cell volumes and abundance using a conversion factor of $0.12 \mathrm{pg} \mathrm{C}$ $\mu^{-3}$ (Eriksson Wiklund et al. 2009). Bacterial growth rate $(\mu)$ was calculated for each replicate according to:

$$
\mu\left(\mathrm{h}^{-1}\right)=\left[\left(\log _{10} N-\log _{10} N_{0}\right) \times 2.303\right] /\left(t-t_{0}\right)
$$

(Stanier et al. 1978) and

$$
\mu\left(\mathrm{h}^{-1}\right)=\left[\left(\log _{10} B b-\log _{10} B b_{0}\right) \times 2.303\right] /\left(t-t_{0}\right)
$$

where $N$ is bacterial abundance per $\mathrm{ml}$, and $B b$ is the carbon biomass (pg C ml-1) at the end of the growth 
phase $(t)$ and at the start of the growth phase $\left(t_{0}\right)$; 2.303 is $\ln (10)$. The lag phase, growth phase and stationary phase were determined empirically from 6 to 9 data points. $\mu$ was calculated for the exponential growth phase, using 2 to 6 data points (median 4). The lowest number of data points (2) was only used for 2 treatments: the highest nutrient concentration in the in situ $+4^{\circ} \mathrm{C}$ treatment on June 25 and the 0.15 addition in the in situ $+4^{\circ} \mathrm{C}$ in July. Replicates were treated separately, and the same number of data points was used for all replicates.

\section{Analysis of bacterial community composition}

To analyze the effect of temperature increase and nutrient availability on the bacterial community composition, samples were taken at the start (lag phase) and at the end (early stationary phase) of 3 of the growth experiments, May 2008, July 2008 and December 2008, for all nutrient levels. At the start, both unfiltered and $0.65 \mu \mathrm{m}$ filtered seawater samples were taken to evaluate if the $0.65 \mu \mathrm{m}$ pre-filtration of the inoculum altered bacterial community composition. All samples for DNA extraction were collected by filtering 100 to $150 \mathrm{ml}$ onto $25 \mathrm{~mm}$ $0.2 \mu \mathrm{m}$ polycarbonate filters, which were stored in Eppendorf tubes at $-80^{\circ} \mathrm{C}$. DNA was extracted using an enzyme/phenol-chloroform protocol (Riemann et al. 2000) but with a 30 min lysozyme digestion at $37^{\circ} \mathrm{C}$ and an overnight Proteinase $\mathrm{K}$ digestion (20 mg $\mathrm{ml}^{-1}$ final conc.) at $55^{\circ} \mathrm{C}$ (Boström et al. 2004). DNA was quantified using PicoGreen (Molecular Probes). Bacterial 16S rRNA genes were PCR amplified using puReTaq Ready-To-Go PCR beads (GE Healthcare), $1.5 \mathrm{ng}$ DNA $\mu \mathrm{l}^{-1}$ and primers GC341F (Muyzer et al. 1993) and 907R (Muyzer et al. 1998) as previously described (Riemann et al. 2006). PCR products were analyzed by denaturing gradient gel electrophoresis (DGGE) as in Riemann et al. (2006). Banding patterns (presence/absence) were transformed into binary data using Quantity One 4 (BioRad).

\section{Statistical analyses}

Effects of sampling occasion/bacterial assemblages, nutrients and temperature on bacterial community growth rates were tested by analysis of variance (ANOVA) using the univariate GLM procedure in SPSS 18 (PASW Statistics 18, release 18.0.0). All sampling occasions except December 2008 had 3 replicates for each combination of 2 temperatures (in situ and in situ $+4^{\circ} \mathrm{C}$ ) and 4 nutrient levels (see Table 1), yielding a total of 24 samples per sampling occasion. December 2008 had 3 replicates at each combination of 3 temperatures $\left(4,8\right.$ and $\left.14^{\circ} \mathrm{C}\right)$ and 3

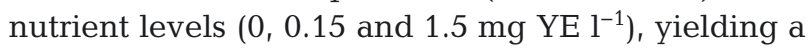
total of 27 samples.

The effects of different sampling occasions/bacterial assemblages on bacterial growth could be studied on a subset of the data, i.e. for sampling occasions that had the same temperatures: (1) December 2007 , December 2008 and May 2008 (all $4^{\circ} \mathrm{C}$ in situ). ANOVA tests were made with the factors sampling occasion, nutrient level and temperature. For the remaining part of the data, it was not possible to separate the effect of sampling occasion from that of temperature on bacterial growth.

The general response of the bacterial community growth to a $4^{\circ} \mathrm{C}$ temperature increase could be tested on the full data set. ANOVA tests were thus performed with the response variables being the differences between growth rate at in situ temperature and at in situ $+4{ }^{\circ} \mathrm{C}$ and with sampling occasion and nutrient level as explanatory factors. In this statistical analysis, the factors sampling occasion and nutrient level indicate potential interaction effects with temperature. The response variables were constructed in the following way: for each combination of sampling occasion and nutrient level, 3 response replicates were formed by randomly matching the 3 samples at in situ temperature with those of in situ $+4^{\circ} \mathrm{C}$. The corresponding differences in growth rates were then computed for each of the 3 matched pairs. Post-hoc tests on 27 marginal means (mean values for the response variable for different combinations of sampling occasion and nutrient levels) were performed to test if the changes were significantly different from zero, thereby indicating that a $4^{\circ} \mathrm{C}$ temperature increase significantly changed bacterial growth. Bonferroni correction was used to adjust the significance level for the multiple comparisons in the post-hoc tests. The individual significance level of each posthoc test was set to $0.1 \%$, yielding an overall significance level of $\sim 5 \%$ for all the multiple comparisons.

The residual analyses of all ANOVAs suggested that the residuals could be assumed normally distributed, homoscedastic, and uncorrelated, thus supporting the applicability of ANOVA.

To study how changes in temperature and nutrient levels affected bacterial community composition over time for specific sampling occasions, multi-dimensional scaling (MDS) plots were produced on the binary transformed DGGE banding patterns from May, July and December 2008, respectively. The 
resemblance matrix based on the Jaccard index was used to create non-metric MDS plots, performed using the package vegan (function metaMDS) in the $\mathrm{R}$ software environment. Permutational multivariate ANOVA (function adonis in the vegan package of $R$ ) was used to test effects of nutrients and temperature on bacterial community composition, measured as Jaccard distance, at the end of the incubations.

\section{RESULTS}

\section{Bacterial community growth rates}

Nutrient enrichment induced increased bacterial growth in all seasons and at all tested temperatures, from 1 to $20^{\circ} \mathrm{C}$ (Fig. 1, see Fig. A1 in Appendix 1). However, the bacterial growth response was de-
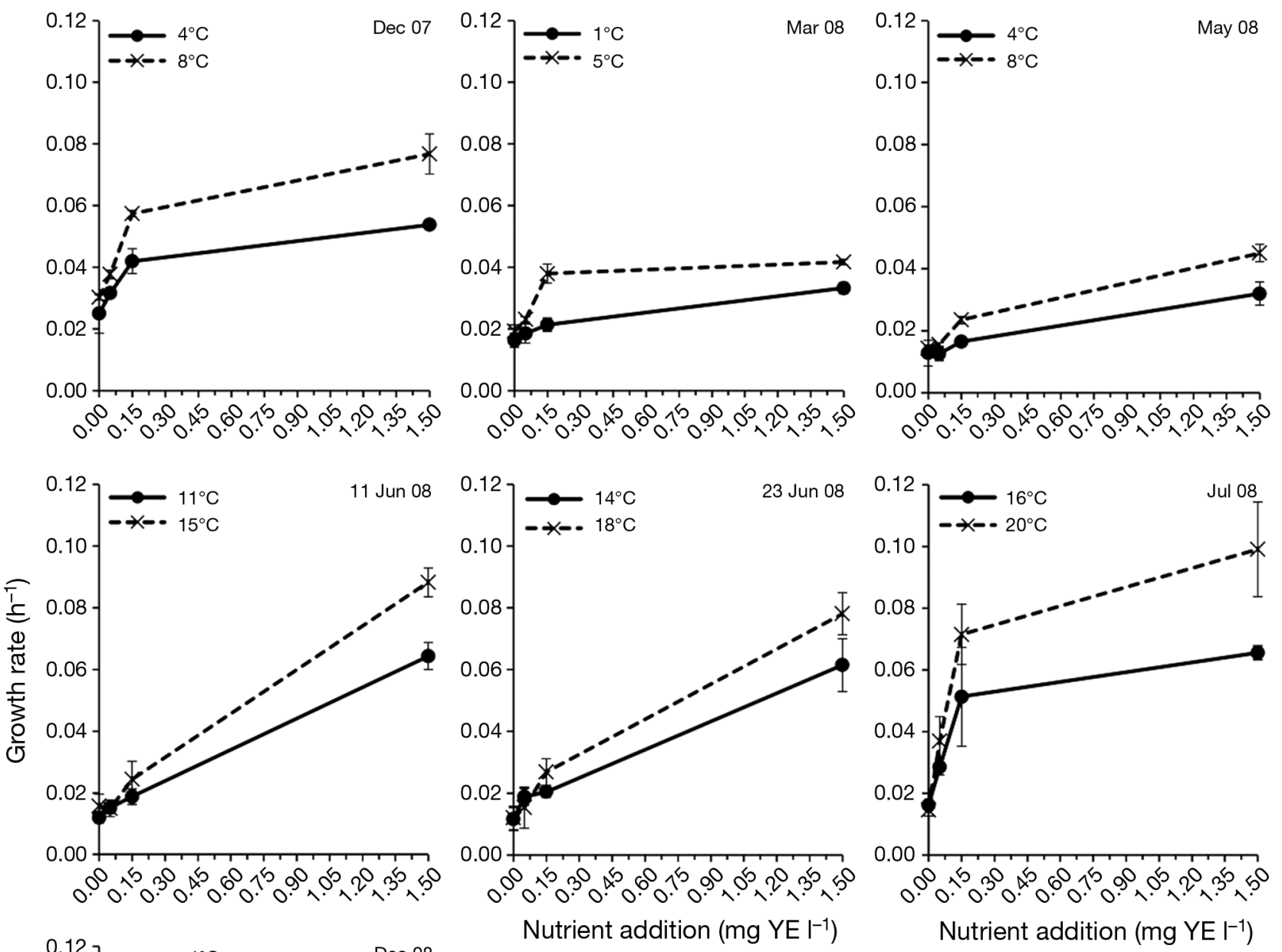

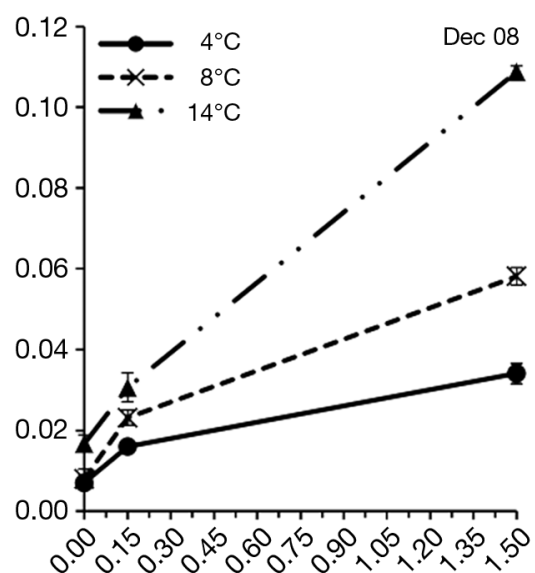

Nutrient addition $\left(\mathrm{mg} \mathrm{YE} \mathrm{I-1)}^{-1}\right.$
Fig. 1. Bacterial community growth rate $\left(\mathrm{h}^{-1}\right)$ at the different sampling occasions with in situ and in situ $+4^{\circ} \mathrm{C}$ temperatures for each nutrient addition

(YE: yeast extract). Error bars denote $\pm \mathrm{SD}$ 
pendent on the incubation temperature and the concentration of the added nutrients, with the lowest response at low nutrient addition and low temperature and the highest at high nutrient addition and high temperature. The highest enrichment level caused a 200 to $700 \%$ increase of the bacterial growth rates compared to the nonenriched treatment, with the lower values observed at the lowest temperature and the higher at the highest temperature (Fig. 1, Fig. A1). Low nutrient additions (0.05 and $0.15 \mathrm{mg} \mathrm{YE}^{-1}$ ) resulted in a 14 to $33 \%$ growth increase during the winter-spring period, while growth increased 9 to $80 \%$ during the summer. Bacterial growth rates estimated from carbon biomass in general yielded values similar to those calculated from cell concentrations (data not shown).

The in situ temperature did not affect the bacterial growth rate very much at the lowest nutrient concentration; in the non-enriched samples, the bacterial community growth rate was relatively similar over the entire temperature interval from 1 to $20^{\circ} \mathrm{C}$ (Fig. 1, Fig. A1). The tested temperature increase of in situ $+4^{\circ} \mathrm{C}$ stimulated bacterial growth rates, especially at high nutrient enrichment (Fig. 2). Temperature increase had a smaller effect on the bacterial community growth rate at low nutrient availability than at high concentrations (Fig. 2). This yielded an interaction between temperature increase and nutrient availability on bacterial growth rate (Table 2).

Bacteria collected at different sampling occasions (December 2007, May 2008, December 2008) and incubated at the same temperatures $\left(4\right.$ and $\left.8^{\circ} \mathrm{C}\right)$ yielded significantly different growth rates and responses to nutrient addition (Table 3), which implies that there were different bacterial assemblages with different growth responses. For example, the growth rates in the $4^{\circ} \mathrm{C}$ non-enriched samples were $0.025,0.013$ and $0.007 \mathrm{~h}^{-1}$ for December 2007, May 2008 and December 2008, respectively. Furthermore, the significant interaction between sampling occasion and nutrients, sampling occasion and temperature, and nutrients and temperature (Table 3) indicates that there was a differential growth rate

Table 2. Effects of bacterial community composition/sampling occasion and nutrient additions on the absolute values of growth change due to increased temperature (in situ + $4^{\circ} \mathrm{C}$ ), tested by analysis of variance using univariate GLM in SPSS 18 on the whole dataset

\begin{tabular}{|lrrl|}
\hline Independent variable & df & $F$ & $\mathrm{p}$ \\
\hline Sampling occasion & 6 & 3.84 & $<0.005$ \\
Nutrient & 3 & 38.59 & $<0.001$ \\
Sampling occasion $\times$ Nutrient & 17 & 2.08 & $<0.05$ \\
Error & 54 & & \\
\hline
\end{tabular}

Table 3. Effect of bacterial community composition/sampling occasion, nutrient addition and temperature $\left(4\right.$ and $\left.8^{\circ} \mathrm{C}\right)$ on the bacterial growth using the subset of sampling occasions with the same in situ temperature $4^{\circ} \mathrm{C}$ (December 2007, May 2008 and December 2008), tested by analysis of variance using univariate GLM in SPSS 18

\begin{tabular}{|lccc|}
\hline Independent variable & df & $F$ & $\mathrm{p}$ \\
\hline Sampling occasion & 2 & 56.10 & $<0.05$ \\
Nutrient & 3 & 17.12 & $<0.05$ \\
Temperature & 1 & 4.38 & 0.1 \\
Sampling occasion $\times$ Nutrient & 4 & 16.24 & $<0.01$ \\
Sampling occasion $\times$ Temperature & 2 & 10.22 & $<0.05$ \\
Nutrient $\times$ Temperature & 3 & 21.31 & $<0.01$ \\
Sampling occasion $\times$ & 4 & 0.83 & 0.5 \\
$\quad$ Nutrient $\times$ Temperature & & & \\
Error & 40 & & \\
\hline
\end{tabular}

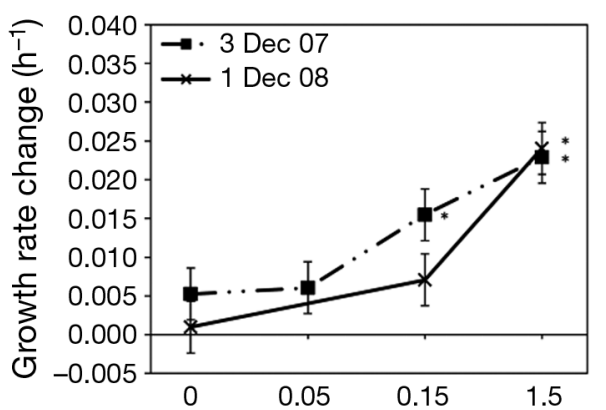

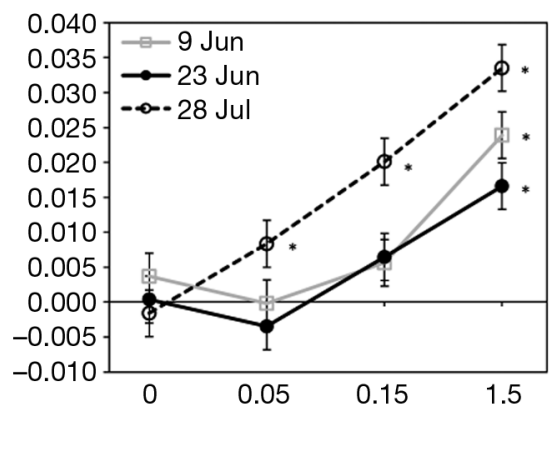

Fig. 2. Growth rate change due to increased temperature (in situ $+4^{\circ} \mathrm{C}$ ) at the different nutrient enrichments and sampling occasions/community compositions. ${ }^{*}$ denotes significant increase in growth rate $(\mathrm{p}<0.05)$ based on post-hoc tests (of individual significance level $0.1 \%$ ) from the ANOVA of Table 2 , with family error rate of $p<0.05$ 
stimulation executed by the $+4^{\circ} \mathrm{C}$ temperature increase. All together, this indicates that different bacterial assemblages have varying community growth rates and growth responses to changed nutrient concentrations and temperature.

The length of the lag-phase decreased rapidly with increasing nutrient concentration and incubation temperature up to $\sim 11^{\circ} \mathrm{C}$ (Fig. 3). At higher temperatures, the shortening of the lag-phase was less pronounced at all nutrient concentrations. For the lowest temperatures, there was a clear difference in the length of the lag-phase from the in situ temperature to the $+4^{\circ} \mathrm{C}$, with a larger difference at low nutrient conditions and less at higher nutrients. The experiments from 23 June and July 2008, which had the highest in situ temperatures, did not show any difference in length of the lag-phase due to increased temperature. Overall, the difference in the length of the lag-phase (due to a $4^{\circ} \mathrm{C}$ temperature increase) varied significantly between sampling occasions and nutrient additions (Table 4).

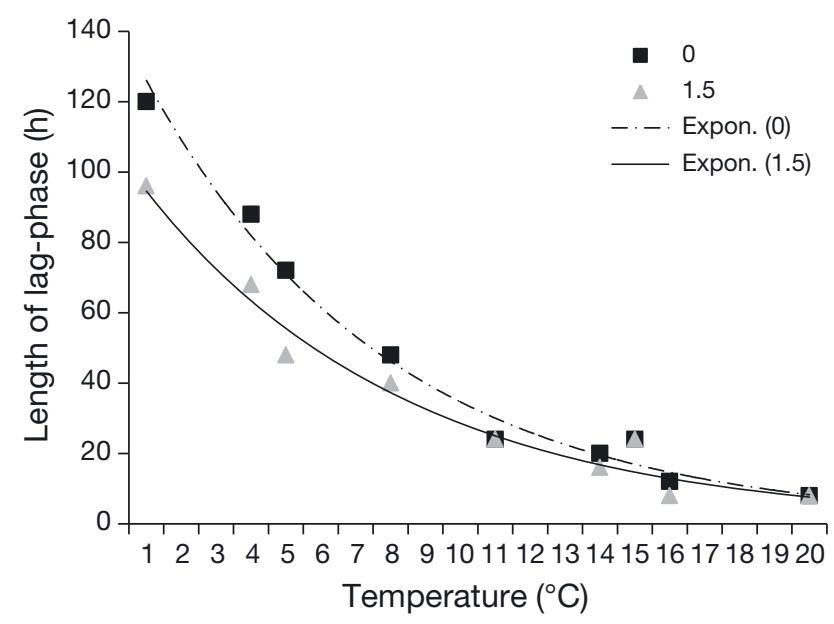

Fig. 3. Length of the lag-phase for the non-supplemented control $\left(0 \mathrm{mg}\right.$ yeast extract $\left.\mathrm{l}^{-1}\right)$ and the highest nutrient enrichment $\left(1.5 \mathrm{mg}\right.$ yeast extract $\left.\mathrm{l}^{-1}\right)$ over the temperature range

Table 4. Effects of bacterial community composition/sampling occasion and nutrient additions on the length of the lag-phase due to increased temperature (in situ $+4^{\circ} \mathrm{C}$ ), tested by analysis of variance using univariate GLM in SPSS 18 on the whole dataset

\begin{tabular}{|lrcc|}
\hline Independent variable & df & $F$ & $p$ \\
\hline Sampling occasion & 6 & $9.97 \times 10^{31}$ & $<0.001$ \\
Nutrient & 3 & $6.98 \times 10^{30}$ & $<0.001$ \\
Sampling occasion $\times$ Nutrient & 17 & $2.86 \times 10^{30}$ & $<0.001$ \\
Error & 54 & & \\
\hline
\end{tabular}

\section{Bacterial community composition}

MDS plots indicated that the bacterial community composition was at least partly affected by temperature and nutrient availability at all 3 studied sampling occasions (Fig. 4). In May, the $4^{\circ} \mathrm{C}$ temperature increase was observed to induce a change in the bacterial communities at the low and intermediate nutrient levels (Fig. 4A). Bacterial communities at the highest nutrient concentration (d: $1.5 \mathrm{mg} \mathrm{l}^{-1}$; see Fig. 4) tended to group together independent of incubation temperature ( $4 \mathrm{~d}$ and $8 \mathrm{~d}$ ). However, permutational MANOVA showed that temperature gave close to significant changes, while nutrients did not give significant alteration of the bacterial community composition (Table 5). The filtered start inoculum differed from that of unfiltered in situ water, indicating that the studied bacterial community differed somewhat from the in situ community.

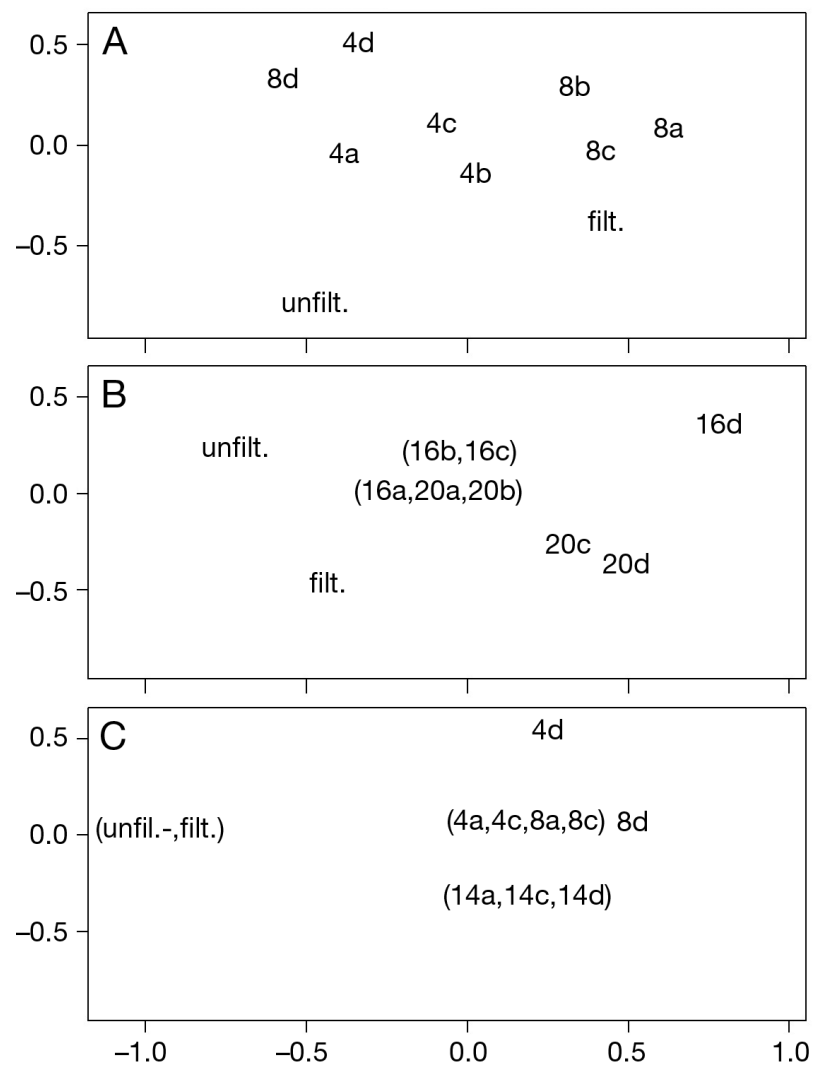

Fig. 4. Multidimensional scaling (MDS) plots based on bacterial community composition in samples from (A) May, (B) July and (C) December 2008. Samples are labelled with incubation temperature, letters correspond to the amount of yeast added; a: $0 \mathrm{mg} \mathrm{l}^{-1}$, b: $0.05 \mathrm{mg} \mathrm{l}^{-1}$, c: $0.15 \mathrm{mg} \mathrm{l}^{-1}$ and d: $1.5 \mathrm{mg} \mathrm{l}^{-1}$. Start samples are labelled unfilt.: in situ water before filtration; filt.: water filtered through a $0.65 \mu \mathrm{m}$ polycarbonate filter. Samples within parentheses are identical 
Table 5. Effect of nutrients and temperature on bacterial community composition during 3 sampling occasions in 2008, measured as Jaccard distance, using the permutational MANOVA test in the software environment R (the start samples were excluded)

\begin{tabular}{|lccc|}
\hline Independent variable & df & $F$ & $\mathrm{p}$ \\
\hline May & & & \\
$\quad$ Nutrient & 3 & 1.45 & 0.28 \\
$\quad$ Temperature & 1 & 3.78 & 0.058 \\
$\quad$ Residuals & 3 & 0.27 & \\
July & & & \\
$\quad$ Nutrient & 3 & 5.29 & 0.084 \\
$\quad$ Temperature & 1 & 4.53 & $<0.05$ \\
$\quad$ Residuals & 3 & 0.13 & \\
December & & & \\
$\quad$ Nutrient & 2 & 0.14 & 0.946 \\
Temperature & 2 & 5.55 & $<0.05$ \\
Residuals & 4 & 0.26 & \\
\hline
\end{tabular}

The MDS plot for July indicated that the bacterial communities in the low and intermediate nutrient levels were different from those at high nutrient concentrations (Fig. 4B). Temperature increase was shown to stimulate different bacterial communities, especially at the highest nutrient concentration (16d and 20d). The permutational MANOVA test showed that temperature increase induced significant alteration of the bacterial community composition, while nutrients showed close to significant changes (Table 5). Also at this sampling occasion, the studied bacterial community $(0.65 \mu \mathrm{m}$ filtered seawater) differed somewhat from the in situ community (unfiltered seawater).

In December, the bacterial assemblages in the low and intermediate nutrient levels grouped together (Fig. 4C), and the $4^{\circ} \mathrm{C}$ temperature increase did not have an effect. Bacterial communities grown at the highest nutrient level differed somewhat from that of the lower nutrient levels, and at this concentration, the $4^{\circ} \mathrm{C}$ temperature change did also induce different bacterial assemblages (see Fig. 4C, samples $4 \mathrm{~d}$ and $8 d)$. The large temperature increase of $10^{\circ} \mathrm{C}$ selected for a distinct bacterial community, grouping irrespective of the nutrient level. It was probably because of the $10^{\circ} \mathrm{C}$ increase that the permutational MANOVA test gave significant differences for temperature, while nutrient additions did not stimulate significant changes of the bacterial communities (Table 5). In contrast to the May and July samplings, the bacterial community in the filtered start inoculum in December was similar to that of unfiltered in situ water, indicating that the studied bacterial community was comparable to the in situ community.
Interactive effects of temperature and nutrients on the bacterial communities could not be tested statistically, due to the lack of replicates, as the replicated samples were pooled before DNA extraction. The MDS plots did, however, indicate that there was an interactive effect between the $4^{\circ} \mathrm{C}$ temperature increase and nutrient availability on bacterial community compositions, with largest effects at the highest nutrient concentrations.

\section{DISCUSSION}

Conclusions drawn from small-scale incubations cannot be directly projected to ecosystem scale processes such as climate change or eutrophication because of enclosure effects (Massana et al. 2001) and the many biological, physical and chemical interactions co-occurring in situ in complex natural systems (Carpenter 1996, Schindler 1998). Nevertheless, simple and small-scale manipulations, like in the present study, can be used to examine functional responses to specific manipulations mimicking environmental perturbations. In the present study, we examine functional responses of Baltic bacterioplankton communities to changed temperature and nutrient availability and discuss results in the face of present atmospheric and oceanographic prediction models (Andréasson et al. 2004, Meier 2006, IPCC 2007).

In accordance with previous studies (Kritzberg et al. 2010, Wohlers-Zöllner et al. 2011), our results suggest that elevated temperatures by a few degrees $\left(4^{\circ} \mathrm{C}\right)$, for example due to climate change, will mainly stimulate bacterial growth rates in nutrient-rich environments, while effects will be relatively minor in oligotrophic regions. Increased temperature may thus not lead to higher growth of the microbial food web in nutrient-constrained environments, as nanoflagellates and ciliates are dependent on bacteria as a food source (e.g. Azam \& Malfatti 2007). It might be speculated that catabolic processes (e.g. respiration) in high temperature and low nutrient treatments would increase relative to anabolic processes (e.g. protein synthesis), leading to a decreased growth rate compared to that at the in situ temperature. However, we did not find any sign of decreased bacterial growth rates at elevated temperature, indicating that there was no significant deviation between anabolic and metabolic processes at low nutrient conditions. This is in agreement with recent studies showing that there is no clear relationship between bacterial growth efficiency and temperature when bacteria 
are constrained by inorganic nutrients (LópezUrrutia \& Moran 2007, Berggren et al. 2010).

The above scenario would be valid in aquatic systems that do not change trophic state as a result of elevated temperature. However, climate change has been predicted to cause a number of alterations affecting aquatic systems, including higher wind speeds and increased precipitation in northern Europe (Andréasson et al. 2004, Meier 2006, IPCC 2007). Higher wind speed would cause increased resuspension of sediments in shallow or coastal systems, which in turn would lead to increased nutrient availability for bacteria. Increased precipitation would increase nutrient loads to coastal systems, potentially leading to eutrophication and phytoplankton blooms (Nixon 1988). At the same time, however, rivers in northern Europe often contain high concentrations of carbon-rich humic substances, which may hamper phytoplankton growth by shading (Wikner \& Andersson 2012). In contrast, growth of heterotrophic bacteria and the microbial food web may be stimulated by this inflow of allochthonous organic matter, which partly can be utilised by bacteria (Bergström et al. 2003). Environments that might not change trophic state in an altered climate include for instance oligotrophic oceans, which are not significantly influenced by freshwater inflow. If, however, the re-suspension increases due to elevated wind speeds as predicted (Meier 2006), nutrient concentrations in the upper water will conceivably increase even in such environments. It thus seems likely that both temperature and trophic state will change in many aquatic systems, in such a way that the heterotrophic microbial food web will be stimulated.

Nutrient addition stimulated bacterial growth rates during the entire annual cycle, but the response to low nutrient additions was minor during the cold season. In general, the highest nutrient addition had the largest effect on bacterial growth rate, particularly during the warm period. Several other studies report larger nutrient-induced (e.g. DOM) increases in bacterial growth rates in warmer waters than in colder waters (Kirchman \& Rich 1997, Autio 1998, Kirchman et al. 2005). These observations are consistent with the 'Wiebe-Pomeroy hypothesis', which argues that bacteria in cold water need more resources to grow than bacteria in warmer water, likely due to decreased fluidity over the cell membrane causing a decreased affinity for nutrients (Gounot 1991, Jumars et al. 1993). We therefore expected a greater effect of nutrient enrichment at higher temperatures, which in turn should lead to an interaction between temperature and nutrient availability on bacterial growth rates. In our study, the interaction was significant, a result consistent with some studies (Gillespie et al. 1976, Griffiths et al. 1984, Pomeroy et al. 1991) but not with others (Rivkin et al. 1991, Felip et al. 1996, Yager \& Deming 1999). This discrepancy may be explained by variations in incubation time or nutrient levels in the different studies.

The lag phase can be considered as a metabolic up-shift period from a relatively dormant stage to active growth. We found that the lag-phase, i.e. the response time, was markedly shortened in response to temperature increase and nutrient additions. This is consistent with earlier findings showing a prolonged lag phase in response to decreased temperature (Buchanan \& Klawitter 1992, Kirchman \& Rich 1997). Hence, it is conceivable that higher temperature and periodically higher inflow of nutrients or resuspension in the coastal pelagic zones induced by climate change would lead to faster bacterial growth responses than is presently the case.

Since bacterial community composition changes with season in the Baltic Sea (Pinhassi \& Hagström 2000, Riemann et al. 2008, Andersson et al. 2010), we expected community successions in response to nutrient amendments and raised temperature. As an anticipated effect of changed conditions and confinement (Massana et al. 2001), the incubated communities differed significantly from the inocula (Fig. 4). Interestingly, the analyzed samples from the 3 lowest nutrient additions ( 0 to $0.15 \mathrm{YE} \mathrm{mg}^{-1}$ ) within each sampling session expressed high similarities, while samples

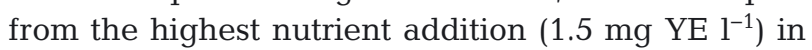
most cases formed separate groups. A temperature increase of $4^{\circ} \mathrm{C}$ did not seem to cause any large differences in the bacterial community composition even though there were some indications in the May samples. In contrast, the $+10^{\circ} \mathrm{C}$ samples in December 2008 did cluster separately from the other temperatures used in that session $\left(4\right.$ and $\left.8^{\circ} \mathrm{C}\right)$. This indicates the existence of a threshold for both temperature and nutrients to induce changes in bacterial community composition. Our data suggest that a small increase in temperature during different seasons would not change bacterial community composition, but if large changes in nutrient levels occur, for example due to increased re-suspension or considerable increase of nutrient-rich river inflow to coastal zones, then the bacterial species assemblages would change and their growth activity increase. This, in turn, would affect bacterial recycling of inorganic nutrients and organic carbon as well as the entire pelagic food web.

In conclusion, the results of the present study indicate that bacterial growth rates and community com- 
position in nutrient-poor systems (e.g. oligotrophic oceans), which will not experience large changes in nutrient concentrations, will only be slightly affected by a $4^{\circ} \mathrm{C}$ temperature increase. However, in eutrophic systems and in systems where nutrient levels will increase considerably, for example due to periodic resuspension and increased river inflow of nutrient-rich freshwater, the bacterial community composition will change, the growth rates will increase, and the response time will decrease compared to the present situation. Thus, due to the combined effect of increased temperature and higher nutrient levels (increased trophic state), heterotrophy mediated by bacterial processing of organic matter would be favored relative to autotrophy, e.g. in coastal zones. Since bacteria-based food webs generally contain more trophic levels than phytoplankton-based webs (e.g. Azam et al. 1983, Berglund et al. 2007), the food web efficiency may consequently decrease. For example, if the carbon flow up the food web becomes channeled via the protozoan community ( $\sim 4$ to $50 \mu \mathrm{m})$ instead of being directly channeled from the basal trophic level to mesozooplankton (200 to $2000 \mu \mathrm{m}$ ), the food web efficiency may decrease as much as 10-fold (e.g. Berglund et al. 2007). In systems where climate change will cause increased bacterial production and decreased primary production (sensu Berglund et al. 2007), fish production may ultimately decrease. Furthermore, a potential shift toward bacterial dominance and an accompanying increase in heterotrophy in aquatic systems (Bergström et al. 2003) would likely cause elevated carbon dioxide emission and a further acceleration of global climate change.

Acknowledgements. We thank Umeå Marine Sciences Centre for field sampling and Dr. O. Rowe for comments on earlier drafts of the manuscript. This project was supported by grants from the Swedish Research Council for Environment Agricultural Sciences and Spatial Planning (FORMAS) to A.A. (217-2006-674) and by the strategic research programme Ecochange to Umeå University and the Linneus University. Contributions by J.D. and L.R. were also supported by the BONUS+ project BAZOOCA (FORMAS 2102008-1882) and the Danish Agency for Science, Technology and Innovation (09-066396) to L.R.

\section{LITERATURE CITED}

Andersson AF, Riemann L, Bertilsson S (2010) Pyrosequencing reveals contrasting seasonal dynamics of taxa within Baltic Sea bacterioplankton communities. ISME J 4: 171-181

> Andréasson J, Bergström S, Carlsson B, Graham P, Lindström G (2004) Hydrological change: climate change impact simulations for Sweden. Ambio 33:228-234
Autio R (1998) Response of seasonally cold-water bacterioplankton to temperature and substrate treatments. Estuar Coast Shelf Sci 46:465-474

Azam F, Malfatti F (2007) Microbial structuring of marine ecosystems. Nat Rev Microbiol 5:782-791

Azam F, Fenchel T, Field JG, Gray JS, Meyer-Reil LA, Thingstad F (1983) The ecological role of water-column microbes in the sea. Mar Ecol Prog Ser 10:257-263

> Berggren M, Laudon H, Jonsson A, Jansson M (2010) Nutrient constraints on metabolism affect the temperature regulation of aquatic bacterial growth efficiency. Microb Ecol 60:894-902

Berglund J, Müren U, Båmstedt U, Andersson A (2007) Efficiency of a phytoplankton-based and a bacteria-based food web in a pelagic marine system. Limnol Oceanogr 52:121-131

Bergström AK, Jansson M, Drakare S, Blomqvist P (2003) Occurrence of mixotrophic flagellates in relation to bacterioplankton production, light regime and availability of inorganic nutrients in unproductive lakes with differing humic contents. Freshw Biol 48:868-877

Bidle KD, Manganelli M, Azam F (2002) Regulation of oceanic silicon and carbon preservation by temperature control on bacteria. Science 298:1980-1984

> Blackburn N, Hagström Å, Wikner J, Hansson RC, Bjørnsen PK (1998) Rapid determination of bacterial abundance, biovolume, morphology, and growth by neural networkbased image analysis. Appl Environ Microbiol 64: 3246-3255

Boström KH, Simu K, Hagström Å, Riemann L (2004) Optimization of DNA extraction for quantitative marine bacterioplankton community analysis. Limnol Oceanogr Methods 2:365-373

Buchanan RL, Klawitter LA (1992) The effect of incubation temperature, initial $\mathrm{pH}$, and sodium chloride on the growth kinetics of Escherichia coli O157:H7. Food Microbiol 9:185-196

> Carlson RE (1977) A trophic state index for lakes. Limnol Oceanogr 22:361-369

> Carpenter SR (1996) Microcosm experiments have limited relevance for community and ecosystem ecology. Ecology 77:677-680

Clarke A, Fraser KPP (2004) Why does metabolism scale with temperature? Funct Ecol 18:243-251

Cubasch U, Meehl GA, Boer GJ, Stouffer RJ and others (2001) Projections of future climate change. In: Houghton JT, Ding Y, Griggs DJ, Noguer M and others (eds) Climate change 2001: the scientific basis. Contribution of Working Group I to the Third Assessment Report of the Intergovernmental Panel on Climate Change. Cambridge University Press, Cambridge, p 525-582

> Eriksson Hägg H, Humborg C, Mörth CM, Rodrigues Medina M, Wulff F (2010) Scenario analysis on protein consumption and climate change effects on riverine $\mathrm{N}$ export to the Baltic Sea. Environ Sci Technol 44: $2379-2385$

Eriksson Wiklund AK, Dahlgren K, Sundelin B, Andersson A (2009) Effects of warming and shifts of pelagic food web structure on benthic productivity in a coastal marine system. Mar Ecol Prog Ser 396:13-25

> Felip M, Pace ML, Cole JJ (1996) Regulation of bacterial growth rates: the effects of temperature and resources. Microb Ecol 31:15-28

Fellman JB, D'Amore DV, Hood E (2008) An evaluation of freezing as a preservation technique for analyzing dis- 
solve organic $\mathrm{C}, \mathrm{N}$ and $\mathrm{P}$ in surface water samples. Sci Total Environ 392:305-312

- Fuhrman JA, Hewson I, Swalbach MS, Steele JA, Brown MV, Naeem S (2006) Annually reoccurring bacterial communities are predictable from ocean conditions. Proc Natl Acad Sci USA 103:13104-13109

Gillespie PA, Morita RY, Jones LP (1976) The heterotrophic activity for amino acids, glucose and acetate in Antarctic waters. J Oceanogr Soc Jpn 32:74-82

$>$ Gounot AM (1991) Bacterial life at low temperature: physiological aspects and biotechnological implications. J Appl Bacteriol 71:386-397

- Griffiths RP, Caldwell BA, Morita RY (1984) Observations on microbial percent respiration values in Arctic and subarctic marine waters and sediments. Microb Ecol 10: 151-164

HELCOM (2007) Climate change in the Baltic Sea area. HELCOM Thematic assessment in 2007. Baltic Sea Environ Proc No. 111, Baltic Marine Environment Protection Commission-Helsinki Commission, Helsinki, p 1-54

Hoppe HG, Gocke K, Koppe R, Begler C (2002) Bacterial growth and primary production along a north-south transect of the Atlantic Ocean. Nature 416:168-171

Hoppe HG, Breithaupt P, Walther K, Koppe R, Bleck S, Sommer U, Jürgens K (2008) Climate warming in winter affects the coupling between phytoplankton and bacteria during the spring bloom: a mesocosm study. Aquat Microb Ecol 51:105-115

IPCC (2007) Summary for policymakers. In: Solomon S, Qin D, Manning M, Chen Z and others (eds) Climate change 2007: the physical science basis. Contribution of Working Group I to the Fourth Assessment Report of the Intergovernmental Panel in Climate Change. Cambridge University Press, Cambridge, p 1-18

Jones RI (1992) The influence of humic substances on lacustrine planktonic food chains. Hydrobiologia 229:73-91

Jumars PA, Deming JW, Hill PS, Karp-Boss L, Yager PL (1993) Physical constraints on marine osmotrophy in an optimal foraging context. Mar Microb Food Webs 7 : 121-159

> Kirchman DL, Rich JH (1997) Regulation of bacterial growth rates by dissolved organic carbon and temperature in the equatorial Pacific Ocean. Microb Ecol 33:11-20

Kirchman DL, Malmstrom RR, Cottrell MT (2005) Control of bacterial growth by temperature and organic matter in the Western Arctic. Deep-Sea Res II 52:3386-3395

Klug JL (2002) Positive and negative effects of allochthonous dissolved organic matter and inorganic nutrients on phytoplankton growth. Can J Fish Aquat Sci 59:85-95

Kritzberg ES, Arrieta JM, Duarte CM (2010) Temperature and phosphorus regulating carbon flux through bacteria in a coastal marine system. Aquat Microb Ecol 58: 141-151

López-Urrutia A, Moran XAG (2007) Resource limitation of bacterial production distorts the temperature dependence of oceanic carbon cycling. Ecology 88:817-822

Martinez J, Smith DC, Steward GF, Azam F (1996) Variability in ectohydrolytic enzyme activities of pelagic marine bacteria and its significance for substrate processing in the sea. Aquat Microb Ecol 10:223-230

> Massana R, Pedrós-Alio C, Casamayor EO, Gasol JM (2001) Changes in marine bacterioplankton phylogenetic composition during incubations designed to measure biogeochemically significant parameters. Limnol Oceanogr 46: 1181-1188
Meier HEM (2006) Baltic Sea climate in the last 21st century: a dynamical downscaling approach using two global models and two emission scenarios. Clim Dyn 27:39-68

Müren U, Berglund J, Samuelsson K, Andersson A (2005) Potential effects of elevated sea-water temperature on pelagic food webs. Hydrobiologia 545:153-165

> Muyzer G, De Waal EC, Uitterlinden AG (1993) Profiling of complex microbial populations by denaturing gradient gel electrophoresis analysis of polymerase chain reaction-amplified genes coding for 16S rRNA. Appl Environ Microbiol 59:695-700

Muyzer G, Brinkhoff T, Nübel U, Santegoeds CM, Schäfer $\mathrm{H}$, Wawer C (1998) Denaturing gradient gel electrophoresis (DGGE) in microbial ecology. In: Akkermans ADL, van Elsas JD, De Bruin FJ (eds) Molecular microbial ecology manual. Kluwer Academic Publishers, London, p 1-27

Nedwell DB (1999) Effect of low temperature on microbial growth: lowered affinity for substrates limits growth at low temperature. FEMS Microbiol Ecol 30:101-111

Nixon SW (1988) Physical energy inputs and the comparative ecology of lake and marine ecosystems. Limnol Oceanogr 33:1005-1025

Pinhassi J, Hagström $\AA$ (2000) Seasonal succession in marine bacterioplankton. Aquat Microb Ecol 21:245-256

Pomeroy LR, Wiebe WJ (2001) Temperature and substrates as interactive limiting factors for marine heterotrophic bacteria. Aquat Microb Ecol 23:187-204

Pomeroy LR, Wiebe WJ, Deibel D, Thompson RJ, Rowe GT, Pakulski JD (1991) Bacterial responses to temperature and substrate concentration during the Newfoundland spring bloom. Mar Ecol Prog Ser 75:143-159

> Reay DS, Nedwell DB, Priddle J, Ellis-Evans JC (1999) Temperature dependence of inorganic nitrogen uptake: reduced affinity for nitrate at suboptimal temperatures in both algae and bacteria. Appl Environ Microbiol 65: 2577-2584

> Riemann L, Azam F (2002) Widespread N-acetyl-Dglucosamine uptake among pelagic marine bacteria and its ecological implications. Appl Environ Microbiol 68: 5554-5562

Riemann L, Steward GF, Azam F (2000) Dynamics of bacterial community composition and activity during a mesocosm diatom bloom. Appl Environ Microbiol 66:578-587

$>$ Riemann L, Titelman J, Båmstedt U (2006) Links between jellyfish and microbes in a jellyfish dominated fjord. Mar Ecol Prog Ser 325:29-42

Riemann L, Leitet C, Pommier T, Simu K, Holmfeldt K, Larsson U, Hagström $\AA$ (2008) The native bacterioplankton community in the central Baltic Sea is influenced by freshwater bacterial species. Appl Environ Microbiol 74: 503-515

Rivkin RB, Anderson MR, Gustafson DE Jr (1991) Dynamics of bacterioplankton growth in McMurdo Sound, Antarctica: evidence for substrate sufficient growth. Antarct J US 26:145-146

Sandberg J, Andersson A, Johansson S, Wikner J (2004) Pelagic food web structure and carbon budget in the northern Baltic Sea: potential importance of terrigenous carbon. Mar Ecol Prog Ser 268:13-29

Schindler DW (1998) Replication versus realism: the need for ecosystem-scale experiments. Ecosystems 1:323-334

> Sommer U, Lengfellner K (2008) Climate change and the timing, magnitude, and composition of the phytoplankton spring bloom. Glob Change Biol 14:1199-1208 
Sommer U, Aberle N, Engel A, Hansen T and others (2007) An indoor mesocosm system to study the effect of climate change on the late winter and spring succession of Baltic Sea phyto- and zooplankton. Oecologia 150:655-667

Stanier RY, Adelberg EA, Ingraham JL (1978) General microbiology, 4th edn. Macmillan Press, London

Swedish Environmental Protection Agency (1999) Assessment of coastal and sea water quality. Report 4914 (in Swedish). Almqvist and Wiksell, Uppsala

- Wikner J, Andersson A (2012) Increased freshwater discharge shifts the trophic balance in the coastal zone of the northern Baltic Sea. Glob Change Biol 18: 2509-2519

- Wohlers-Zöllner J, Breithaupt P, Walther K, Jürgens $\mathrm{K}$, Riebesell U (2011) Temperature and nutrient stoichiometry interactively modulate organic matter cycling in a pelagic algal-bacterial community. Limnol Oceanogr 56: 599-610

Yager PL, Deming JW (1999) Pelagic microbial activity in an arctic polynya: testing for temperature and substrate interactions using a kinetic approach. Limnol Oceanogr $44: 1882-1893$

Appendix 1. Bacterial response to lowest and highest nutrient conditions

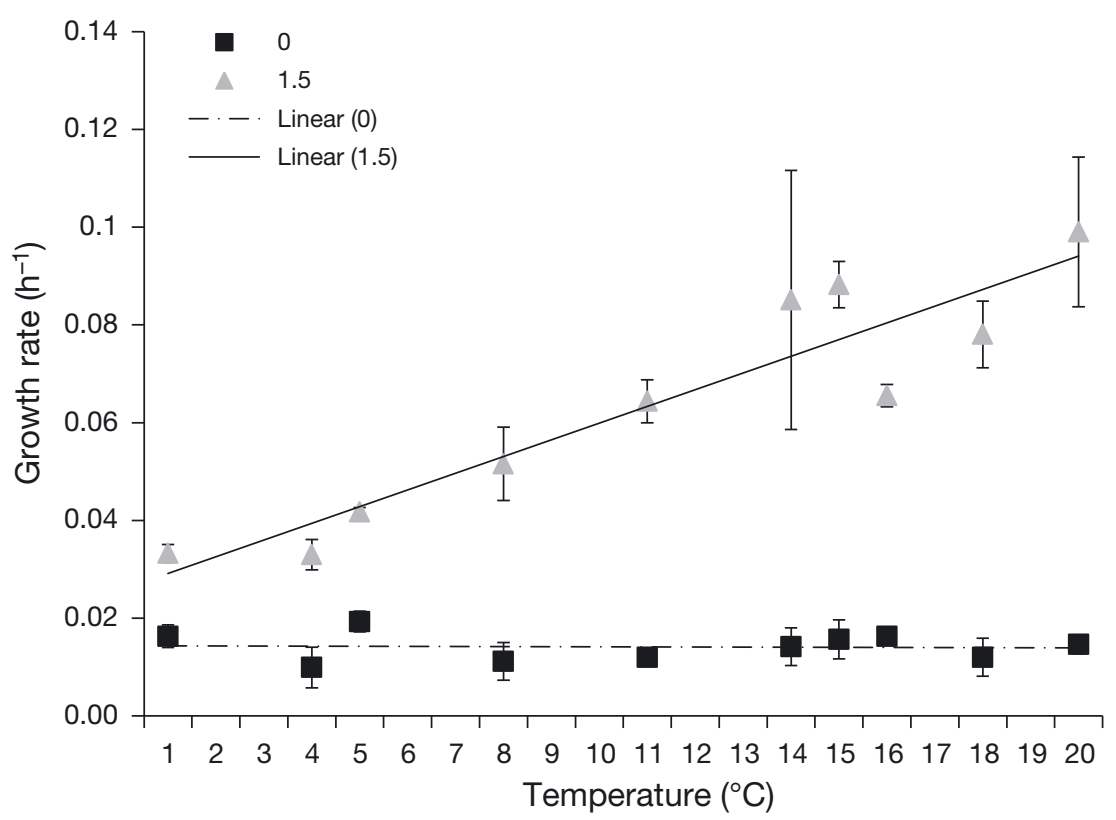

Fig. A1. Bacterial community growth rate at all tested temperatures for the non-supplemented control $\left(0\right.$ mg yeast extract $\left.\mathrm{l}^{-1}\right)$ and the highest nutrient enrichment $\left(1.5 \mathrm{mg}\right.$ yeast extract $\left.\mathrm{l}^{-1}\right)$. Error bars denote $\pm \mathrm{SD}$

Editorial responsibility: Josep Gasol, Barcelona, Spain
Submitted: June 7, 2012; Accepted: November 20, 2012

Proofs received from author(s): January 22, 2013 